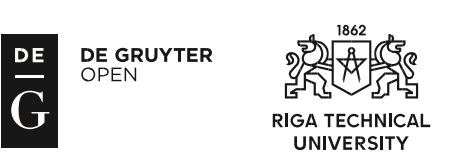

\title{
INDUSTRY SPECIFICS AND CONSUMERS' REACTIONS TO BUSINESS CRISES
}

\author{
Asta KAZLAUSKIENE் \\ ISM University of Management and Economics, Lithuania \\ Corresponding authore-mail: kazlasta@stud.ism.lt
}

\begin{abstract}
Different scientific studies provide many valuable recommendations how to manage crises in order to lessen their negative effect on relations with consumers. But the question whether the same business crises management rules can be applied for different industries, or they must be adapted depending on industries specifics, has not received sufficient scientific attention. Knowledge gaps about industry specific effect on consumer reactions to business crises remain. This study focuses on understanding the differences in consumers' reactions in business crises situations with regard to controversial evaluation in the society of "the sin industries" (alcohol, tobacco, gambling, etc.) and ordinary industries (not having controversial associations). Experimental research design, including online experiment with tobacco, beer and functional soft drinks consumers (in total 306 respondents), was chosen for competing research hypotheses testing. Empirical evidence was in line with theoretical argumentation about less negative consumers' reactions during business crises in case of "sin industries" versus ordinary industry. This study shows that consumers attitudes, such as perception of company's product quality, trust, social responsibility and behavioural intentions, such as intention to buy and recommend company's products, are less negative during business crises in lower reputation "sin industries" than in ordinary industries.
\end{abstract}

Keywords: Business crises, consumer attitudes, consumer reactions, experiment, industry specific, sin industries, purchase intension.

JEL Classification: M31, M14.

\section{INTRODUCTION}

The rapid technological progress, globalization and mobile technologies determine that today we are living in the era of crises (Lerbinger, 2012), when consumers in no time learn of the problems or crises experienced by the companies. The messages on the problems related to quality of different products, accidents occurring on their production places, environmental disasters and different acts of organizational misdeed are widely covered by media, rapidly disseminated in social networks and continuously discussed with friends and acquaintances. In such conditions consumers cannot remain apathetic to the information - many studies conducted in the past two decades (Mohr \& Webb, 2005; Johnson \& Grayson, 2005; Zhao, Zhao \& Helsen, 2011; Cleeren, Heerde \& Dekimpe, 2013; Haas-Kotzegger \& Schlegelmilch, 2013; Grappi \& Romani, 2015; Lin et al., 2011; Ahluwalia, Burnkrant \& Unnava, 2000; Assiouras, Ozgen \& Skourtis, 2013; Dean, 2004; 
Coombs \& Holaday, 2007; Klein \& Dawar, 2004) show that consumers change their attitude and/or behaviour towards crisis experiencing companies and their products. Therefore, business organizations have no other choice but to accept crises as unavoidable reality and learn to manage them in order to minimize their negative impact on the relations with consumer. This is especially important for the companies operating in the industries, which experience crises more often only due to their product specifics. Among those are the so called "sin industries". Different scholars (Davidson, 2003; Keane, 2006; Kim \& Venkatachalam, 2011 and others) most frequently define alcohol, tobacco and gambling business as sin industries, others also mention legal pornography and weapons business.

There are few scientific studies and research analyzing the problems of sin industries. American scholar Davidson was among the first, who commenced the discussion on the specifics of sin industries in 1995. In the later years, there have been studies analyzing the investors' behaviour towards sin industries. These researches have shown that the so called "sin stocks", with the spread of trends of socially responsible investing, receive less and less attention from investors, despite their high profitability. Having analyzed different factors affecting investors' behaviour, Hong \& Kasperczyk (2009) and Kim \& Venkatachalam (2011) came up to the conclusion that investors, especially institutional ones, are inclined to reject sin stocks as the result of pressure from the society and unwillingness to get involved in moral conflicts. Can similar trends in consumers' behaviour be noticed? This question still is open in scientific literature. It is not a secret that most crises management theories and scientific recommendations on the issue are prepared based on the studies of ordinary industry companies (in this study ordinary industries are defined as those that do not receive controversial attitude from the public or consumers due to specifics of their products or business). Therefore, still there is a lack of studies in scientific literature analyzing whether the same business crises management recommendations can be applied to different industries, or they must be adapted depending on industry specifics. The present paper is devoted to bridging this research gap. The aim of this study is to understand how consumers' reactions (attitudes and behavioural intentions) to business crises differ in sin and ordinary industries. To gain a comprehensive view of the research problem different theoretical perspectives were analyzed and competing hypotheses were formulated considering how industry specifics can affect consumers' reactions during business crises. Empirical testing was performed using experimental research design. Differences in consumers' reactions were identified by simulating crises in tobacco and beer industries (sin industries) and functional and soft drinks industry. Finally, conclusions were provided, research limitations and possible future research areas were discussed.

\section{LITERATURE SURVEY AND HYPOTHESES DEVELOPMENT}

\subsection{Business Organization Crises, Their Concept and Principal Aspects}

When discussing organizational crises, different scholars (Hwang \& Lichtenhal, 2000; Bronn \& Berg, 2009; Lerbinger, 2012) stress the aspects of their 
suddenness and the element of surprise, they also mention the unbalance of the organization's usual functioning, the necessity of quick decision making, different negative consequences and significant psychological stress. The threat to reputation quite frequently is the indicator allowing for distinguishing between a routine and a crisis situation.

The following essential factors determining the consequences of a crisis and their effect on the company's reputation could be distinguished (Coombs, 2004; Coombs, 2007; Coombs \& Holladay, 2006; Coombs \& Holladay, 2007):

1. Character of a crisis, the level of its severity and the level of responsibility for the crisis, attributed to the company by the stakeholders.

Crises may be very difficult and complicated, however, if the stakeholders, including the consumers, do not see any fault of the company for the crises, the damage to the company's reputation will be significantly smaller than in case the crisis is a result of a lack of competence, negligence or wilful acts of the company's managers or employees. Depending on the level of responsibility for the crises, attributed to the organization, Coombs $(2004,2007)$ distinguished three clusters of crises. The first, the Victim Cluster, includes the crises, as the result of which the organization also becomes a victim. Such crises are characterized with a week responsibility for the crisis, attributed to the organization. Among such crises are natural disasters, rumours, on-job violence, outside damage to the products. The second, the Accidental Cluster, covers the crises, resulting from unintentional actions of the organization, for instance, accidents or products defects resulting from technical errors. In case of such a crisis, the organization incurs the average responsibility for the consequences. The third, the Preventable Cluster, includes the crises, during which the organization condemns people to risk and, being aware of that, takes inappropriate actions or violates the law (for instance, accidents or product defects (recalled products) as a result of human error or criminal activities of the heads of the organization). In such case, organizations incur a high level of responsibility for the crisis and its consequences.

2. History of organization crises and pre-crisis reputation.

Specific consequences of a crisis also depend on the earlier crisis experience and pre-crisis reputation of the organization. The more positive is the company's reputation before the crisis, the smaller number of crises the company has experienced in the past or the better the company managed to deal with the crises, the higher is the expectation that during the crisis the company will be more favourably viewed by different stakeholders, including the consumers. In such case, the consequences of the crisis will be less severe (Dowling, 2002; Coombs, 2004 and 2007; Coombs \& Holladay, 2006; Lerbinger, 2012; French \& Holden, 2012).

3. Earlier relations with stakeholders.

The earlier reputation among stakeholders shows how the organization has treated the stakeholders in other contexts and situations. Such valuations do not necessarily have to be objective, it is sufficient that the stakeholders, including the consumers, perceive their relations with the organization as good or as bad (Coombs, 2007).

The consequences of a crisis also depend on how the organization is able to manage the crisis, which crisis management strategy it chooses and how it 
communicates with the stakeholders (Dowling, 2002; Coombs, 2007; Alpaslan, Green \& Mitroff, 2009; Lerbinger, 2012). Quite frequently, communication is the factor determining the success of crisis management, as well as the financial and reputation damage.

As the importance of choosing a proper crisis management strategy is undeniable, the scientific literature provides theories and recommendations on how a company should act in case of a crisis. One of such theories is well known Situational Crisis Communication Theory (SCCT), developed by Coombs (2004, 2007). This theory states that a response to a crisis in order to protect the reputation of the company must be chosen in consideration of the specific type of the crisis and evaluating others factors, important in the specific situation (such as the earlier crisis history, pre-crisis reputation of the company, relations with the stakeholders). According to Coombs SCCT, depending on the crisis type and situational factors, the crisis response strategies best fitting in particular situation may be chosen. When an organization finds itself in a crisis, for which the stakeholders do not attribute the responsibility to the organization (a victim type crisis), the company has no history of similar crises, its relations with the stakeholders and the pre-crisis reputation are good, the organization may choose the defensive crisis response strategies. In case of more complicated conditions, the company may choose the strategies of excuse and deemphasizing the damage done by the crisis. In most complicated conditions (high attribution of the responsibility and negative situational factors), the most compromise and adaptation oriented strategies are suitable. In such cases, the organizations usually take full responsibility for the crisis and its consequences, apologize to the victims and offer them help and compensations. According to Coombs (2007), such crisis response strategies may significantly help to restore the company's reputation; however they are the most expensive and may require significant financial resources.

The crisis itself, also response and communication strategies chosen by the organization, stir certain emotions in people (Coombs, 2007). Influenced by such emotions and the perceived reputation of the organization, company's stakeholders including consumers shape their attitude and choose a certain position regarding the organization. All of the above determines their future actions. Findings of the study by Grappi and Romani (2015) based on real Costa Concordia shipwreck crisis are in line with Coombs ideas. Their study shows the mediating role of emotions (anger and sympathy) and the moderating role of corporate reputation, which moderates effect of post-crisis communication strategies on consumers' reactions (attitudes to the company, the intention to buy its products and negative world-of-mouth communication).

\subsection{Consumers' Reactions, Attitudes and Behavioural Intentions Changes in the Business Crisis Situations}

Ajzen (1991) Theory of Planned Behaviour states that attitudes are important indicators of behavioural intentions and real behaviour. For this reason, it is important to understand how consumers' attitudes and behavioural intentions change during business crises. 
Perception of the products' quality. The following two sources may be distinguished, based on which consumers make their decision on the quality of products (Zhao et al., 2011; Miklós-Thal \& Zhang, 2013): 1) personal experience related to a product or service; 2) different additional signals, such as information on the price of a product, different guarantees and advertisements. The crises, experienced by companies, may also be attributed to certain signals, affecting consumers' opinion of the products' quality. Erdem and Keane (1996) state that consumers face a certain level of uncertainty when evaluating quality and such uncertainty reduces with the increase of the amount of information, reaching the consumer. However, Zhao et al. (2011) are of another opinion - when the information and signals are totally different from the previous ones, for instance, in a crisis situation, the level of uncertainty grows significantly and, in such case, the perception of quality may significantly change during a short period of time. These authors' research shows that crises have a negative effect on the perceived product quality.

Trust in the company. Social trust is among the most important variables determining the consumers' choice, it helps foresee the consumers' behaviour and create strong consumer relations and ensure their loyalty (Uhlmann et al., 2010; Sirdeshmukh, Singh \& Sabol, 2002). Meanwhile, trust in the company is important to the consumers since it simplifies their decisions on the choice of products or services. Therefore, consumers are usually very sensitive to damage of their trust (Uhlmann et al., 2010), which is integral to crisis situations in case of spread of negative information about the company. Negative news usually quickly reduces the consumers' emotional and cognitive trust in the company. Johnson and Grayson (2005) relate emotional trust with emotional perception and evaluation of the extent the organization cares for its consumers and other stakeholders. Meanwhile, the consumers' opinion about competences, knowledge and skills held by the company is attributed to cognitive trust. The study performed by Uhlmann et al. (2010) has shown that in case the company responds in the appropriate manner during the crisis situations and shows attention to the stakeholders, it is easier to restore the emotional trust. The cognitive trust is more difficult to restore since competences are not quickly acquired.

Perception of the company's social responsibility. More and more heads of companies throughout the world state that they are concerned with environmental protection, health, security, labour environment and social problems by adding value both to their companies and to stakeholders. According to Madden, Roth and Dillon (2012), successful CSR actions on the market turn into positive attitude towards products, intention to buy and consumers' satisfaction with the products. The companies offering attractive and reliable social initiatives, which consumers wish to associate and identify with, satisfy the especially important need of selfperception and assignment to certain groups (Bhattacharya \& Sen, 2003). Although there exist a positive relation between the CSR activity and the consumer's attitude towards the company, consumers are more sensitive to negative information on companies' social responsibility, or its absence (Mohr \& Webb, 2005). In the context of crisis, it is usually visible if a company dedicated insufficient attention 
to a certain area, attributed to social responsibility, such as environmental protection or security of labour environment.

Intention to buy and recommend. Recently scholars have been dedicating more and more attention to studying buying behaviour during crisis and post-crisis periods. Scientific literature (Zhao et al., 2011; Cleeren et al., 2013; HaasKotzegger \& Schlegelmilch, 2013; Coombs \& Holladay, 2007; Lin et al., 2012; Ahluwalia et.al., 2000; Assiouras et al., 2013) gives no doubts of the negative effect of crises on intentions to buy and recommend crisis affected products. The negative relation between crises and buying or intention to buy is substantiated by experimental studies (Assiouras et al., 2013), consumers' surveys (Lin et al., 2012; Cleeren et al., 2013) and analysis of secondary data, such as sales volumes and market shares (Zhao et al., 2011; Cleeren et al., 2013).

To summarize the data of the discussed studies, it could be stated that during the crisis consumers' reactions acquire a negative character. Studies in this area (Mohr \& Webb, 2005; Johnson \& Grayson, 2005; Zhao et al., 2011; Cleeren et al., 2013; Haas-Kotzegger \& Schlegelmilch, 2013; Grappi \& Romani, 2015; Lin et al., 2011, Ahluwalia et al., 2000; Assiouras et al., 2013; Dean, 2004; Coombs \& Holaday, 2007; Klein \& Dawar, 2004) have provided consistent conclusions - most important consumers attitudes, such as perceptions of companies' products quality and social responsibility, trust in the company, also behavioural intentions, such as intention to buy and recommend company's products, change in negative direction during the business crisis.

\subsection{The Specifics of Sin Industries}

In order to understand whether the industry's specifics has any influence on the consumers' reactions, it is important to understand the peculiarities of the chosen industries. Sin industries are viewed upon ambiguously due to the following reasons: 1) their collision with social norms and morality (Cai, Jo \& Pan, 2012) and 2) potentially negative social consequences or negative effects on health (Lindorff, Prior Jonson \& McGuire, 2012). The list of businesses, attributed to sin industries, is slightly different in different scholars' studies. Some scholars attribute adult entertainment and pornography business to sin industries (Davidson, 2003; Kim \& Venkatachalam, 2011), while others include the industry of manufacturing weapons, intended for self-defence (Kean, 2006; Davidson, 2003). However, there is a unanimous agreement that alcohol, tobacco and gambling business should be attributed to sin industries (Hong \& Kasperczyk, 2009; Kim \& Venkatachalam 2011; Davidson, 2003; Kean, 2006). Sin industries significantly differ from each other by their products and services, their spread level, etc., although there also are many similarities, especially when discussing the environment, in which such businesses function. Some might characterize their environment as hostile. However, according to Davidson (2003), such hostility is not related to the products' consumers. The sin products satisfy consumers' needs, therefore they consume them with enjoyment, while the hostility is determined by the fact that a certain, large or sufficiently important in order to be heard part of the society has the opinion that such products are unacceptable. As mentioned above, although such products are strongly regulated, they are fully legal. However, a certain part 
of the society considers such products offensive, inappropriate or even dangerous due to various reasons. Thus, sin industry representatives find themselves in an environment of incompatible contradictions. They must not only overcome the challenges, faced by all the companies, i.e. organize their activities in an everchanging economic environment, respond to the growing competition, satisfy the continuously growing needs of consumers', but also overcome a significant social and quite often political and regulatory opposition. This determines that crises is more frequent in the sin industries environment. According to Kean (2006), the specifics of sin industries program conflict situations between stakeholders. Quite frequently regulatory authorities and groups of activists manipulate information and even attempt to start such conflicts in order to attract the widest possible attention from the public. They attempt to affect the public's emotions, rather than to resolve the painful issue as quickly as possible by means of reasoned arguments. Kean (2006) notes that the emotional intensity of sin industries depends on the spread of products and reputation of the industry. It is natural that due to the collision with the socially acceptable norms, the sin industries are characterized by a lower reputation than other industries, manufacturing "innocent" products. However, certain differences may also be noted between the sin industries, for instance, alcohol consumption situations are rather frequent and alcohol is widely accessible to the public, therefore its reputation is relatively better than tobacco or gambling industries.

\subsection{Hypotheses Development}

Although consumers reactions to the crises in sin industries have still not been analyzed in scientific literature deeply, referring to the above discussed theories and studies on organizational crises, consumers' attitudes and behaviour and the particularities of sin industries, certain assumptions on the ways the sin industries' specifics could affect the consumers' reactions to crisis situations could be formulated. Coombs (2004, 2007) Situational Crisis Communication Theory emphasizes that the level of severity and consequences of a crisis depend on the pre-crisis reputation of the company, earlier crisis history and relations with the stakeholders. This theory is used when discussing the consequences of the crises faced by separate companies or organizations. However, attempting to transfer this theory from the organizations' level to the industries' level, one could formulate the assumption that in crises situations sin industry companies will attain more negative reactions from the stakeholders, including consumers, than the representatives of ordinary industries. This assumption would be substantiated by the specifics of sin industries, which determines that sin industries face controversial view of their activities, attacks from activists' groups, a greater legal and supervisory regulation and, as the result, significantly more frequent negative publicity. This means that companies belonging to sin industries due to the specifics of the industry alone experience crises more frequently, therefore, they have a worse crisis history. The continuous moral debate on the issue of sin industries results in the situation where the sin industries' reputation is lower than that of the "harmless" industries. It is natural that the relations with the stakeholders, which include hostile activists' groups and strict regulatory authorities, cannot be as good as in case of ordinary 
industries. Therefore, the first assumption is that consumers will be stricter towards sin industry companies during crisis.

However, the idea expressed by Davidson (2003) that sin industries' consumers are satisfied with and enjoy the sin products, which satisfy their needs, allows thinking that sin industries consumers do not have high expectations for such industries. As sin industries have lower pre-crisis reputation, negative crises history comparing with ordinary industries, consumers are more prepared to see sin industries misbehaving compared to ordinary industries. Lower expectations can be the reason for lower level of disappointment and fewer negative reactions during business crisis. This leads to the assumption that consumers will not have a more negative attitude towards sin industries during the crisis and their reactions may be more positive comparing with ordinary industries.

Based on the mentioned assumptions 2 competing hypotheses were formulated:

H1a. Consumer reactions to business crises will be more negative in sin industries vs. ordinary industries.

H1b. Consumers reactions to business crises will be less negative in sin industries vs. ordinary industry.

These hypotheses were tested empirically.

\section{METHODS AND PROCEDURES OF THE EMPIRICAL RESEARCH}

Experimental research design was chosen for hypotheses testing. Online experiment was selected as the research method. Experiment involved two experimental groups and one control group, in total, 306 people. The experimental groups were formed of sin industry consumers. Two different sin industries were selected for research - tobacco industry with very negative pre-crises reputation and beer industry having less negative reputation (representative of alcohol industry). Soft and functional drinks consumers were chosen as a control group.

The experiment involved 18-50 years old residents of major cities of Lithuania, voluntary registered in the internet database of one of the largest Lithuanian research agencies. In order to ensure the biggest possible similarity and comparability of the experimental and control groups, the simple random respondents' selection method was used for the study. After performing the respondents' selection procedure, further analysis was done using the answers to questionnaire of three different experiment groups: soft/functional beverages and tobacco groups - 100 participants each, the beer group - 106 participants.

Experiment groups were formed only from consumers of a selected industry's products. That resulted in certain differences in the participants' demographic characteristics. There were more male consumers in the beer and tobacco groups, while the soft and functional beverage consumers, in terms of gender, were distributed quite similarly (Table 1). Referring to the data of adult Lithuanian residents' lifestyle survey, performed in 2012 (Grabauskas et al, 2013), this corresponds to the realistic picture of consumers of the mentioned categories of goods. 
Table 1. Demographic characteristics of experiment participants

\begin{tabular}{|l|c|c|c|}
\hline \multirow{2}{*}{} & \multicolumn{3}{|c|}{ Percentage distribution } \\
\cline { 2 - 4 } & $\begin{array}{c}\text { Control group } \\
\text { (soft drinks), } n=100\end{array}$ & $\begin{array}{c}\text { Experiment group } \\
\text { No. 1 (beer), } n=106\end{array}$ & $\begin{array}{c}\text { Experiment group } \\
\text { No. 2 (tobacco), } n=100\end{array}$ \\
\hline Gender: & & & 59.0 \\
\hline Men & 55.0 & 65.1 & 41.0 \\
\hline Women & 45.0 & 34.9 & 29.0 \\
\hline Age: & & & 35.0 \\
\hline $18-29$ y.o. & 36.0 & 34.0 & 36.0 \\
\hline $30-39$ y.o. & 37.0 & 34.0 & \\
\hline $40-50$ y.o. & 27.0 & 32.0 & \\
\hline
\end{tabular}

During the online experiment the participants received three stimuli: first, an attractive description of a fictitious company was provided to all the experimental groups. The only difference between the descriptions of the company provided to different groups was the company's products (soft and functional drinks vs. beer vs. cigarettes and other tobacco products). In the second phase of the experiment, the respondents were given the second stimulus, i.e. the information on the environmental crisis, experienced by the fictitious company: the company discharged hazardous waste into the environment and contaminated the lakes and ground waters, existing in the vicinity thus causing damage to the nature and creating hazard to the health of local residents. During the third phase, the participants were provided the response from the company, by which the company expressed its regret and apology for the accident, explained its circumstances and undertook full responsibility for the consequences and their elimination. Response the stimuli are provided in Appendix.

In each phase, after providing the stimulus, the participants were provided the same questionnaire for evaluating the consumers' reactions: perception of the products' quality, trust in the company, perception of the company's social responsibility and intention to buy and recommend the company's products. To operationalize consumer reaction constructs the scales were adapted that had been validated in the previous research. Consumer reactions were measured based on the following scales:

- Sprott and Shimp (2004) scale was adapted for the purpose of research and was used for perception of product quality measurement.

- The scale first suggested by Sirdeshmukh et al. (2002) was used for trust measurement. Later this scale was adapted including additional item and used in Lin et al. (2011) research.

- Perception of social responsibility was measured according to the scale first used by Currás-Pérez, Bigné-Alcañiz and Alvarado-Herrera (2009), after that it was adapted by Lin et al. (2011).

- The scale validated by Petroshius and Monroe (1987), as well as by Berens, van Riel and van Bruggen (2005) was adapted and used to measure the intention to buy. 
Total 12-item scale was prepared to measure consumers' reactions after respondents received each of experiment stimuli. All items were measured on the 7-point Likert scale, where 1 meant total disagreement and 7 - total agreement with the statements. The measures of reliability were assessed using Cronbach's alpha coefficients. All consumer reaction constructs (perception of the product quality, trust in the company, perception of the company's social responsibility and intention to buy and recommend the company's products) displayed reasonable level of internal consistency: Cronbach's alphas between 0.76 and 0.96 .

\section{RESULTS OF THE RESEARCH}

The data of the experiment are provided in Table 2. For evaluating the consumers' response when provided different stimuli, mean values were calculated and their standard deviations were evaluated. For identifying the statistically significant data differences t-tests were employed: paired samples t-test was used for evaluating the same respondents' response when changing the stimulus, independent samples t-test was used for comparing the responses between different experiment groups.

Table 2. Means and standard deviations in different experiment groups

\begin{tabular}{|l|c|c|c|c|c|c|c|}
\hline \multirow{2}{*}{ Constructs } & \multicolumn{2}{c}{$\begin{array}{c}\text { Soft and } \\
\text { functional drinks } \\
\text { group, } n=100\end{array}$} & \multicolumn{2}{c|}{$\begin{array}{c}\text { Beer group, } \\
n=106\end{array}$} & \multicolumn{2}{c|}{$\begin{array}{c}\text { Tobacco group, } \\
n\end{array}$} \\
\cline { 2 - 7 } & M & SD & M & SD & \multicolumn{2}{c|}{ M } & SD \\
\hline \multirow{2}{*}{ Quality perception } & 4.84 & 1.08 & 4.81 & 1.11 & 4.74 & 1.23 \\
\hline Trust & 4.77 & 1.24 & 4.62 & 1.35 & 4.65 & 1.30 \\
\hline Social responsibility perception & 5.05 & 1.38 & 4.90 & 1.49 & 4.65 & 1.67 \\
\hline Intention to buy and recommend & 4.63 & 1.36 & 4.52 & 1.42 & 4.47 & 1.38 \\
\hline & & Stimulus $2-$ Crisis information & \\
\hline Quality perception & 2.95 & 1.51 & 3.24 & 1.51 & 3.54 & 1.55 \\
\hline Trust & 2.83 & 1.49 & 2.99 & 1.46 & 3.15 & 1.43 \\
\hline Social responsibility perception & 2.67 & 1.65 & 2.62 & 1.45 & 2.66 & 1.66 \\
\hline Intention to buy and recommend & 2.63 & 1.53 & 2.75 & 1.58 & 3.11 & 1.50 \\
\hline & \multicolumn{7}{|c|}{ Stimulus 3-Company response } \\
\hline Quality perception & 3.57 & 1.55 & 3.84 & 1.39 & 4.05 & 1.32 \\
\hline Trust & 3.87 & 1.67 & 3.99 & 1.55 & 4.04 & 1.47 \\
\hline Social responsibility perception & 3.78 & 1.80 & 4.00 & 1.67 & 4.03 & 1.62 \\
\hline Intention to buy and recommend & 3.26 & 1.64 & 3.83 & 1.44 & 3.87 & 1.45 \\
\hline
\end{tabular}

The results of the experiment clearly show that in crisis situations consumers' reactions to the company and its products change in the negative direction (Table 2). 
This trend is visible in all experiment groups - after receiving information about crises (stimulus 2), in all experiment group consumer attitudes (company's quality perception, trust, social responsibility perception) and intention to buy company's products changes are significant $(p<0.05)$ comparing with the initial attitudes and behavioural intentions (evaluation after receiving stimulus 1). Research results also are in line with the ideas that properly chosen company's response may mitigate the consequences of the crisis. However, such response is insufficient for restoring the company's reputation to the pre-crisis level - all groups participating in the experiment displayed statistically significant difference $(p<0.05)$ between the consumers' reactions before the crisis, upon receiving the information on the crisis and after the company's response (see Table 2).

Analyzing the between groups results it was noticed that the consumers' reactions in case of sin industries tend to be less negative. Comparing the response of consumers of soft drinks vs. beer group the trend is clearly visible, however, the difference of reactions is not statistically significant, while comparing the soft drinks with tobacco groups statistically significant differences exist (Figure 1). Differences are significant in quality perception and intention to buy and recommend company's products evaluations: in tobacco group, product quality related consumer attitudes and intention to buy company's products after consumers received information about the crisis suffer less comparing with soft drinks group. The same tendency is visible in consumer evaluation also after consumers received information about the company's response (Table 2 and Fig. 1).

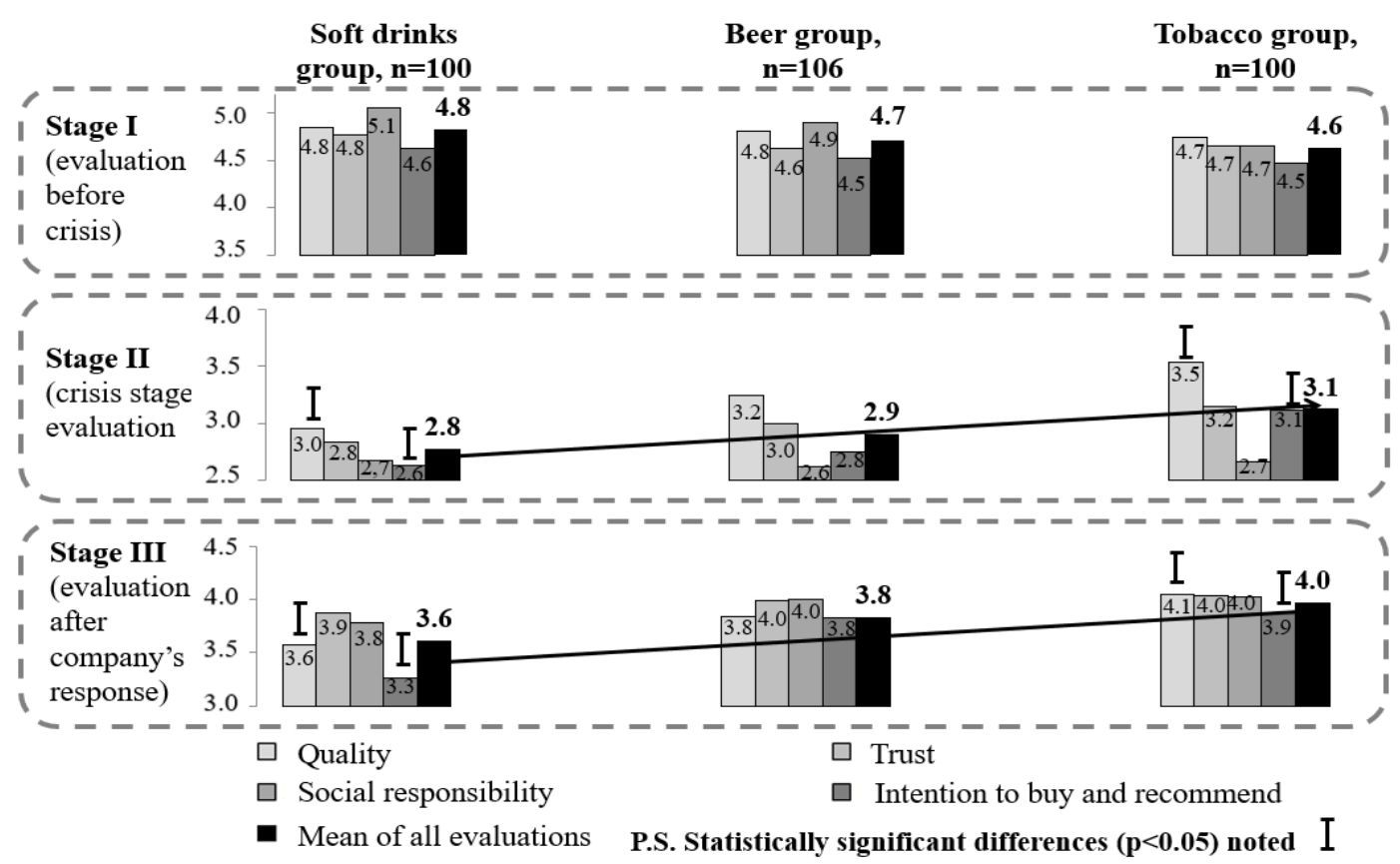

Fig. 1. Comparison of the results of experiment between the control and experimental groups during different phases of the experiment (the mean averages of evaluation of consumers' reactions are provided on a 7 points scale). 
The trend of less negative consumers' reactions during the business crisis is even more prominent when comparing not the reactions itself but the difference between reactions (Figure 2).

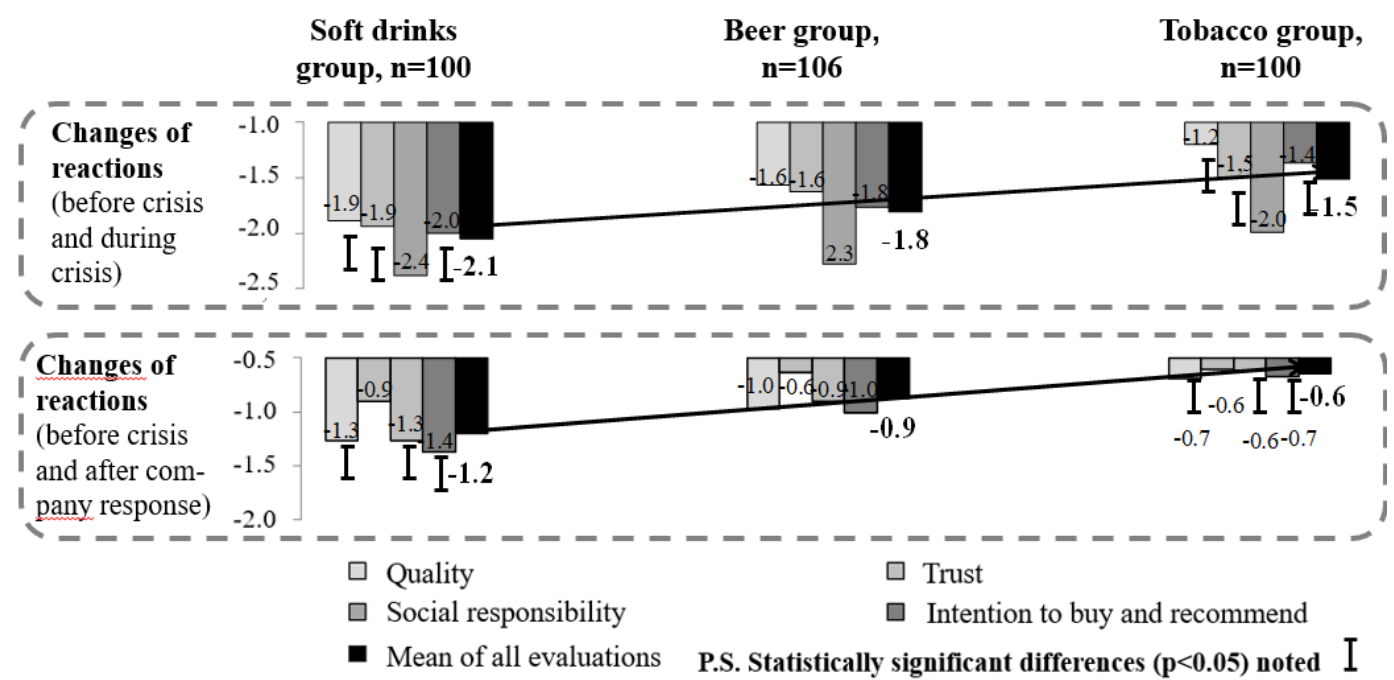

Fig. 2. The difference of the change of consumers' reactions between the groups.

In all groups during the crisis consumers' reactions acquired the negative direction: after consumers received information about the crises in all groups social responsibility dimension suffered most, but after appropriate company's response this dimension recovery was quite successful, while trust in the company was the dimension, which in all groups after receiving appropriate company's response was recovering less.

Overall comparing consumers' reactions changes in all experiment groups it can be stated that research results are in line with H1b hypothesis - consumers' reactions to business crises tend to be less negative in sin industries vs. ordinary industry. This tendency is prominent when comparing beer and ordinary industry research data and statistically significant comparing tobacco and ordinary industry consumer reaction data.

\section{DISCUSSION AND CONCLUSIONS}

The results of the study substantiated the results of previous studies (Mohr \& Webb, 2005; Johnson \& Grayson, 2005; Zhao et al., 2011; Cleeren et al., 2013; Haas-Kotzegger \& Schlegelmilch, 2013; Grappi \& Romani, 2015; Lin et al., 2011; Ahluwalia et al., 2000; Assiouras et al., 2013; Dean, 2004; Coombs \& Holaday, 2007; Klein \& Dawar, 2004), showing that during the crisis consumers' reactions to the company and its products change in the negative direction and this tendency can be observed regardless of the industry. Nevertheless, the study showed that there are differences between the reactions of consumers depending on the industry. Based on the study results, it can be concluded that when consumers have lower expectations related to the product, for example, in case of sin industries, their 
reactions to business crises are less negative comparing with higher expectations related products, such as ordinary industry products. These findings are in line with Kean's (2006) ideas and visible comparing the results between sin industries: industries having relatively lower reputation (tobacco vs. beer) receive more positive consumer reactions during crises.

This study contributes to bridging knowledge gaps about consumers' reactions to business crises in different industries and creates scientific value showing that industry context is important when analyzing consumers' reactions to business crises. The study indicates that additional factor, such as industry context, must be evaluated using Coombs $(2004,2007)$ crisis assessment methodology and STCC theory recommendations. Based on the industry, different response strategies can be used facing the same type of the crisis. These findings also have practical significance and provide insights for managers about the importance of industry specifics evaluation developing crises management strategies and reacting to the business crises.

Limitations and future research. This study provides valuable insights into how consumer reactions differ during the crisis in case of different type of industries. Nevertheless, the performed study characterizes the issue with certain limitations and raises additional questions, which require future investigations.

First, research was limited to studying only two sin industries - alcohol and tobacco. The beer category, which is viewed as the least "sinful", was chosen to reflect the alcohol industry; therefore, the difference of the consumers' response was not statistically significant. One may discuss the trend of less negative response in sin industries when evaluating the beer consumers' response only in the common context with the results of the tobacco industry. In order to have the full view of the effect of the alcohol industry on the consumers' reactions during the crisis, an experiment with consumers of strong alcohol should also be performed. Apart from tobacco and alcohol, scholars also unanimously attribute the gambling business to sin industries. Therefore, in order to make more comprehensive conclusions in the context of sin industries, it is necessary to study consumers' response to the crises in the gambling services and verify whether the gambling services are characterized with the same trends as the product-based sin industries.

Second, the method of experiment, despite its principal advantage, i.e. the possibility to accurately identify the causative relations by controlling experiment conditions able to affect the results of research, has one drawback - it can study only a very limited number of stimuli. Therefore, as the environmental crisis stimulus (accidental crisis type according to Coombs (2007) classification) was chosen for the study, future investigations are needed to understand whether the results of research would be the same in case other types of crisis are chosen.

Third, pursuing the purpose to reflect real industry situations in the experiment as much as possible, our respondents were chosen based on the industry consumer profile, for this reason our experiment groups were not identical by demographic characteristics. This fact may determine some bias in the study results. Despite its more artificial and real life detached conditions, additional experiment with more homogenous experiment group participants can allow making more rigorous 
scientific conclusions about industry effect on consumers' reactions to business crises.

Fourth, in this study functional soft drinks products were chosen as an ordinary industry representative, study replication with other ordinary industries would allow achieving higher generalizability of study results.

\section{REFERENCES}

Ahluwalia, R., Burnkrant, R. E., \& Unnava, H. R. (2000). Consumer Response to Negative Publicity: The Moderating Role of Commitment. Journal of Marketing Research, 37(2), 203-214. https://doi.org/10.1509/jmkr.37.2.203.18734

Ajzen, I. (1991). The theory of planned behavior. Organizational Behavior and Human Decision Processes, 50(2), 179-211. https://doi.org/10.1016/0749-5978(91)90020-t

Alpaslan, C. M., Green, S. E., \& Mitroff, I. I. (2009). Corporate Governance in the Context of Crises: Towards a Stakeholder Theory of Crisis Management. Journal of Contingencies and Crisis Management, 17(1), 3849. https://doi.org/10.1111/j.1468-5973.2009.00555.x

Assiouras, I., Ozgen, O., \& Skourtis, G. (2013). The impact of corporate social responsibility in food industry in product-harm crises. British Food Journal, 115(1), 108-123. https://doi.org/10.1108/00070701311289902

Bhattacharya, C. B., \& Sen, S. (2003). Consumer-Company Identification: A Framework for Understanding Consumers' Relationships with Companies. Journal of Marketing, 67(2), 76-88. https://doi.org/10.1509/jmkg.67.2.76.18609

Bronn, S. P. \& Berg, R. W (2009). Corporate communication: A strategic approach to building reputation. 2nd edition, Oslo: Gyndeldal akademisk.

Berens, G., Riel, C. B. M. van, \& Bruggen, G. H. van. (2005). Corporate Associations and Consumer Product Responses: The Moderating Role of Corporate Brand Dominance. Journal of Marketing, 69(3), 35-48. https://doi.org/10.1509/jmkg.69.3.35.66357

Cai, Y., Jo, H., \& Pan, C. (2011). Doing Well While Doing Bad? CSR in Controversial Industry Sectors. Journal of Business Ethics, 108(4), 467-480. https://doi.org/10.1007/s10551-011-1103-7

Cleeren, K., van Heerde, H. J., \& Dekimpe, M. G. (2013). Rising from the Ashes: How Brands and Categories Can Overcome Product-Harm Crises. Journal of Marketing, 77(2), 58-77. https://doi.org/10.1509/jm.10.0414

Coombs, W. T. (2004). Impact of Past Crises on Current Crisis Communication: Insights From Situational Crisis Communication Theory. Journal of Business Communication, 41(3), 265-289. https://doi.org/10.1177/0021943604265607

Coombs, W. T. (2007). Protecting Organization Reputations During a Crisis: The Development and Application of Situational Crisis Communication Theory. Corporate Reputation Review, 10(3), 163-176. https://doi.org/10.1057/palgrave.crr.1550049

Coombs, W.T., \& Holladay, S. J. (2006). Unpacking the halo effect: Reputation and crisis management. Journal of Communication Management, 10(2), 123-137. https://doi.org/10.1108/13632540610664698

Coombs, W.T. \& Holladay, S. J. (2007). The negative communication dynamic: Exploring the impact of stakeholder affect on behavioral intentions. Journal of Communication Management, 11(4), 300-312. https://doi.org/10.1108/13632540710843913

Currás-Pérez, R., Bigné-Alcañiz, E., \& Alvarado-Herrera, A. (2009). The Role of Self-Definitional Principles in Consumer Identification with a Socially Responsible Company. Journal of Business Ethics, 89(4), 547564. https://doi.org/10.1007/s10551-008-0016-6

Davidson, D. K. (2003). Selling Sin: The marketing of socially unacceptable products, 2nd edition. Westport, CT: Praeger.

Dean, D. H. (2004). Consumer Reaction to Negative Publicity: Effects of Corporate Reputation, Response, and Responsibility for a Crisis Event. Journal of Business Communication, 41(2), 192-211. https://doi.org/10.1177/0021943603261748

Dowling, G. (2002). Creating corporate reputations: Identity, image, and performance. New York: Oxford University Press.

Erdem, T., \& Keane, M. P. (1996). Decision-Making Under Uncertainty: Capturing Dynamic Brand Choice Processes in Turbulent Consumer Goods Markets. Marketing Science, 15(1), 1-20. https://doi.org/10.1287/mksc.15.1.1

French, S. L., \& Holden, T. Q. (2012). Positive Organizational Behavior. Business Communication Quarterly, 75(2), 208-220. https://doi.org/10.1177/1080569912441823 
Grabauskas, V., Klumbienė, J., Petkevičienè, J. Šakyte, E., Kriaučionienė, V., and Veryga, A. (2013). Suaugusių Lietuvos žmonių gyvensenos tyrimas, 2012. Kaunas: Lietuvos sveikatos mokslų universitetas Medicinos akademija. Retrieved from http://vddb.library.lt/fedora/get/LT-eLABa0001:B.03 2013 ISBN_978-9955-15-319-1/DS.001.0.01.BOOK

Grappi, S., \& Romani, S. (2015). Company Post-Crisis Communication Strategies and the Psychological Mechanism Underlying Consumer Reactions. Journal of Public Relations Research, 27(1), $22-45$. https://doi.org/10.1080/1062726x.2014.924839

Haas-Kotzegger, U. \& Schlegelmilch, B. B. (2013). Conceptualising consumers experiences of product-harm crises. Journal of Consumer Marketing 30(2), 112-120. https://doi.org/10.1108/07363761311304924

Hong, H., \& Kacperczyk, M. (2009). The price of sin: The effects of social norms on markets. Journal of Financial Economics, 93(1), 15-36. https://doi.org/10.1016/i.jfineco.2008.09.001

Hwang, P., \& Lichtenthal, J. D. (2000). Anatomy of Organizational Crises. Journal of Contingencies and Crisis Management, 8(3), 129-140. https://doi.org/10.1111/1468-5973.00132

Johnson, D., \& Grayson, K. (2005). Cognitive and affective trust in service relationships. Journal of Business Research, 58(4), 500-507. https://doi.org/10.1016/s0148-2963(03)00140-1

Keane, T. P. (2006). Exploring stakeholder emotional intelligence. Management Research News, 29(3), 128138. https://doi.org/10.1108/01409170610661062

Kim, I., \& Venkatachalam, M. (2011). Are Sin Stocks Paying the Price for Accounting Sins? Journal of Accounting, Auditing \& Finance, 26(2), 415-442. https://doi.org/10.1177/0148558x11401222

Klein, J. \& Dawar, N. (2004). Corporate social responsibility and consumers' attributions and brand evaluations in a product-harm crisis, International Journal of Research in Marketing, 21(3), 203-217. https://doi.org/10.1016/j.ijresmar.2003.12.003

Lerbinger, O. (2012). The Crisis Manager: Facing Disasters, Conflicts, and Failures. New York: Routledge.

Lin, C.-P., Chen, S.-C., Chiu, C.-K., \& Lee, W.-Y. (2011). Understanding Purchase Intention During ProductHarm Crises: Moderating Effects of Perceived Corporate Ability and Corporate Social Responsibility. Journal of Business Ethics, 102(3), 455-471. https://doi.org/10.1007/s10551-011-0824-y

Lindorff, M., Prior Jonson, E., \& McGuire, L. (2012). Strategic Corporate Social Responsibility in Controversial Industry Sectors: The Social Value of Harm Minimisation. Journal of Business Ethics, 110(4), 457-467. https://doi.org/10.1007/s10551-012-1493-1

Madden, T. J., Roth, M. S., \& Dillon, W. R. (2012). Global Product Quality and Corporate Social Responsibility Perceptions: A Cross-National Study of Halo Effects. Journal of International Marketing, 20(1), 42-57. https://doi.org/10.1509/jim.11.0016

Miklós-Thal, J., \& Zhang, J. (2013). (De)marketing to Manage Consumer Quality Inferences. Journal of Marketing Research, 50(1), 55-69. https://doi.org/10.1509/jmr.11.0432

Mohr, L. A., \& Webb, D. J. (2005). The effects of corporate social responsibility and price on consumer responses. Journal of Consumer Affairs, 39(1), 121-147. https://doi.org/10.1111/j.17456606.2005.00006.x

Petroshius, S. M., \& Monroe, K. B. (1987). Effect of Product-Line Pricing Characteristics on Product Evaluations. Journal of Consumer Research, 13(4), 511-519. https://doi.org/10.1086/209084

Sirdeshmukh, D., Singh, J., \& Sabol, B. (2002). Consumer Trust, Value, and Loyalty in Relational Exchanges. Journal of Marketing, 66(1), 15-37. https://doi.org/10.1509/jmkg.66.1.15.18449

Sprott, D. E., \& Shimp, T. A. (2004). Using product sampling to augment the perceived quality of store brands. Journal of Retailing, 80(4), 305-315. https://doi.org/10.1016/j.jretai.2004.10.006

Uhlmann, E., Tannenbaum D., Heinze, J. Srinivasan, M., Brescoll, V.L., Newman G., Galinsky, A. \& Diermeier, D. (2010). The role of trust in reputation management. Retrieved 10/05/20140 from http://www.kellogg.northwestern.edu/reputationrules/reputationlab/docs/TrustAndReputationManag ement.pdf

Zhao, Y., Zhao, Y., \& Helsen, K. (2011). Consumer Learning in a Turbulent Market Environment: Modeling Consumer Choice Dynamics After a Product-Harm Crisis. Journal of Marketing Research, 48(2), 255-267. https://doi.org/10.1509/jmkr.48.2.255 


\section{AUTHORS' SHORT BIOGRAPHY}

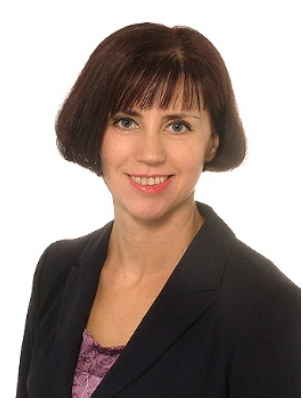

Asta Kazlauskienė is a PhD candidate at ISM University of Management and Economics, Lithuania. She received the Master's degree in Business Administration from Kaunas University of Technology in 2000. She also received Executive Master of Management degree from ISM University of Management and Economics and BI Norwegian Business School in 2014. She has 15 years professional experience in marketing and brand management.

Her main fields of scientific interest are consumer behavior, consumers' reactions to business crises, business crises management and prevention, corporate social responsibility.

E-mail: kazlasta@stud.ism.lt

\section{Appendix \\ Stimuli of the Experiment}

\section{General information about company stimulus}

ADV Holding UAB produces and sells, in Lithuania and in other countries, soft and functional beverages, intended for adults (the beverages are enriched by vitamins and minerals and are intended for persons, going in for sports and living healthy lifestyle) / beer / cigarettes and other tobacco products. The company flexibly responds to the consumers' needs and dedicates significant attention to the quality of its products, i.e. continuously invests into new production and quality control technologies, as well as into development of qualification of its staff. The company cares for safe working environment, uses natural resources sparingly and performs environment contamination prevention. ADV Holding UAB is also known as an active community member, sponsoring culture and sports events and contributing to social programmes, aimed at reduction of poverty, encouraging education and assisting persons with disabilities.

\section{Crises stimulus}

You have found the message, presented below, in a popular Internet news portal, which you trust. Please, read it carefully.

The Environmental Protection Inspectorate reports that a plant, owned by ADV Holding UAB, has ejected a large amount of nonylphenol into the environment. It is suspected that the contamination has spread to the local waters, i.e. the river close to the plant and, from the river - to the two nearby lakes. It is suspected that the local ground waters and the water in the residents' wells are also contaminated. Nonylphenols are hazardous chemical substances, the industrial use of which is going to be prohibited before 2020. Nonylphenols do damage to living organisms, including fish. The said substances may cause cancer, do harm to foetus and result in genetic disorders.

\section{Company response stimulus}

Responding to the event ADV Holding UAB issued a press release. Please, read it carefully.

$\mathrm{We}$, the management of ADV Holding UAB, are very sorry for the incident and the spread contamination. First, we would like to ask the local residents not to drink the water from wells, not bathe in local waters and not eat the fish, caught there. The painful accident was a result of human error, since an employee of our company did not notice the precautionary information about the fault of the wastewater treatment equipment. Our company undertakes full responsibility for the incident. At present independent environmental impact investigators from Germany have taken water samples and are evaluating the real level of contamination. Referring to the results, the company will search for the ways to remove the contaminants from the environment.

We are happy with the good and long-lived relations with the splendid local community and the works that we have done together. We have contributed to the good of the community for a long time and we will resolve the problem with full responsibility. 